\title{
Urgensi Pendidikan Kebencanaan Kepada Masyarakat
}

\author{
Nur Hamid ${ }^{1}$ \\ ${ }^{1}$ Fakultas Dakwah dan Komunikasi, Universitas Islam Negeri Walisongo Semarang, Indonesia \\ Email: elnur.hamid@walisongo.ac.id
}

\begin{abstract}
Disaster is going to happen whenever and wherever people are. Not every area is equipped with early warning system towards disasters, alleviating people panic to become extremely serious issues that need solution. This publication aims to highlight the significance of disaster education for society so they can act accordingly when disaster strikes. Method used on this study was literature study method which is a method conducting by reading, scrutinizing, acknowledging, outlining, and analyzing literatures from books, journals, and secondary data related to disaster education. The study revealed that up to this time, there have been not a reliable method to employ for disaster education either in formal and non-formal education yet, even in informal one. However, in general, disaster education that can represent and be adopted as an alternative is in forms of disaster training, activities to promote people awareness, introduction of the topic through work publication, workshop or seminar, simulation, exhibition, and other activities based on local wisdom.
\end{abstract}

\section{Keywords : Disaster, Disaster Education for Society, Local Wisdom.}

Abstrak. Bencana akan terjadi kapanpun dan dimanapun kita berada. Tidak semua wilayah memiliki alat peringatan dini terhadap bencana sehingga kepanikan masyarakat terhadap bencana akan menjadikan masalah yang sangat serius dan harus diberikan solusi. Tujuan tulisan ini adalah menekankan pentingnya pendidikan kebencanaan kepada masyarakat agar masyarakat dapat mengambil tindakan yang benar ketika terjadi bencana. Metode yang digunakan dalam penelitian ini adalah metode studi pustaka yaitu metode yang dilakukan dengan membaca, mencermati, mengenali, menguraikan, dan menganalisis literatur-literatur dari buku, jurnal, dan data-data sekunder yang berhubungan dengan pendidikan kebencanaan. Hasil penelitian menunjukkan bahwa sampai saat ini belum ada metode yang tepat yang dapat digunakan dalam memberikan pendidikan kebencanaan, baik dalam lingkungan pendidikan formal, pendidikan non formal, ataupun pendidikan informal. Tetapi secara umum pendidikan kebencanaan yang dapat mewakili dan dapat digunakan alternatif yaitu pendidikan kebencanaan berupa pelatihan tentang kebencanaan, kegiatan peningkatan kesadaran masyarakat terhadap bencana, mengenalkan pemahaman melalui publikasi karya, workshop atau seminar kebencanaan, simulasi dan pameran kebencanaan, dan kegiatan kapasitas lainnya yang berbasis kearifan lokal masyarakat.

Kata Kunci : Bencana, Pendidikan Kebencanaan kepada Masyarakat, Kearifan Lokal Masyarakat

\section{PENDAHULUAN}

Salah satu cara untuk mentransfer pengetahuan dan pengalaman adalah melalui pendidikan. Pendidikan dapat diperoleh melalui pengajaran, pelatihan, belajar otodidak ataupun penelitian yang dapat digunakan sebagai pengetahuan dalam menentukan suatu hal. Sikap dan tindakan dalam melakukan suatu hal tidak dapat dipisahkan dengan lingkungan sekitarnya, hal ini sangat berkaitan dengan pendidikan masyarakat yang diperoleh baik secara formal, nonformal, ataupun informal. Hal ini berkaitan dengan yang dijelaskan Henderson (1947) bahwa pendidikan tidak memisahkan antara body dan mind, begitu pula dengan lingkungan, pendidikan tidak memisahkan antara manusia dengan lingkungannya. Lingkungan dimana seseorang berada tidak hanya lingkungan materi atau lingkungan fisik saja melainkan juga lingkungan sosial. 
Tujuan utama dari pendidikan adalah memberikan suatu informasi dan pemahaman kepada individu ataupun kelompok terhadap obyek dalam pembelajaran yang dapat meningkatkan kapasitasnya (Black, Smeyer, Smith, \& Standish, 2003). Salah satunya adalah pendidikan kebencanaan yang belum banyak diberikan kepada anak sekolah, mahasiswa ataupun masyarakat yang terdampak bencana. Dalam tulisan ini akan lebih banyak membahas pendidikan kebencanaan di masyarakat karena masyarakat adalah subyek sekaligus obyek dalam pembelajaran kebencanaan.

Pendidikan kepada masyarakat akan lebih diminati jika masyakarat dilibatkan secara langsung dalam menganalisis permasalahan yang ada disekitarnya sesuai pengalamannya. Pengalaman inilah yang paling penting dalam merumuskan pendidikan kebencanaan kepada masyarakat, masyarakat akan menceritakan pengalaman-pengalaman yang pernah dialami pada saat terjadi bencana ataupun melihat bencana di wilayah lainnya yang kebetulan mereka mengetahuinya. Pengalaman memberikan catatan khusus kepada kita bahwa masyarakat perlu dikupas secara detail pengalamannya terkait dengan kejadian sehari-hari yang ada di sekitarnya (Winch \& Gingell, 2008).

Konsep pendidikan kebencanaan dimulai dengan memberikan pengetahuan khusus terkait bencana yang ada di lingkungannya, masyarakat diberikan bekal pengalaman dan pemahaman terkait bencana yang sering terjadi di sekitarnya. Terkait dengan konsep pendidikan, Barrow \& Woods (2006) menjelaskan bahwa pendidikan adalah suatu hal yang bernilai yang ditransmisikan secara sengaja dengan cara yang dapat diterima secara moral. Jadi, pengetahuan dan pengalaman mengenai kebencanaan adalah suatu nilai yang berharga dan wajib diberikan kepada masyarakat yang membutuhkan. Hal inilah yang membuktikan bahwa pendidikan tidak harus diperoleh melalui sekolah ataupun universitas, tetapi juga dapat diperoleh melalui lingkungan yang ada di sekitar kita (Hamid, 2018).

Melalui pendidikan kebencanaan ini tentunya memiliki tujuan khusus dalam membangun masyarakat (community development) yang lebih sadar terhadap kelestarian lingkungan, mengerti terhadap permasalahan lingkungan, dan mengerti kondisi lingkungan yang buruk yang akan menimbulkan bencana. Tahapan dalam pendidikan kebencanaan tidak lepas dengan suatu proses yang akan menuju tujuan akhir, dalam proses tersebut sangat ditekankan dalam pelibatan masyarakat dalam melakukan segala hal, karena masyarakat bukan obyek yang merupakan tujuan atau hasil dari proses akan tetapi masyarakat merupakan beribu-ribu proses perubahan secara terus menerus. Masyarakat memiliki pengetahuan umum dalam mendiskripsikan lingkungannya, masyarakat memiliki peran penting dalam lingkungannya, hal ini karena masyarakat setiap harinya hidup di lingkunyannya yang lebih mengetahui segala hal dari tempat tinggalnya daripada orang lain yang tidak pernah hidup di tempat tersebut. Oleh karena itu perlu di integrasikan antara pengetahuan masyarakat mengenai lingkungan dan bencana dengan ilmu pendidikan kebencanaan yang telah diteliti oleh peneliti di seluruh dunia.

Berdasarkan hal diatas, perlunya referensi yang berkaitan dengan pendidikan kebencanaan dalam pengembangan masyarakat secara utuh yang dapat memberikan informasi kepada siapapun yang membutuhkannya. Tulisan ini ditulis berdasarkan sumber dari penelitian-penelitian terdahulu yang di review dari beberapa jurnal mengenai pendidikan kebencanaan dalam konteks pengembangan masyarakat yang bertujuan untuk menambah wawasan mengenai pentingnya pendidikan kebencanaan yang harus ditanamkan kepada masyarakat.

\section{METODE PENELITIAN}

\section{Jenis penelitian}

Tulisan ini disajikan dalam bentuk kajian pustaka (library research) yaitu upaya penelitian yang dilakukan dengan membaca, mencermati, mengenali, dan menguraikan hingga menganalisa bahan bacaan berupa buku-buku perpustakaan dan literatur-literatur yang terkait sebagai sumber rujukan (John W. Creswell, 2013; Muri Yusuf, 2014). Adapun bahan bacaan yang menjadi fokus kajian dalam penelitian ini adalah setiap sumber literatur yang berkaitan dengan pendidikan kebencanaan. 


\section{Sumber penelitian}

Tulisan ini menggunakan sumber data penelitian dari literatur-literatur yang terkait dengan tema penelitian (Deni Darmawan, 2013). Literatur tersebut berupa buku, hasil penelitian dari jurnal nasional dan jurnal internasional, dan beberapa data sekunder yang lain mengenai pendidikan kebencanaan.

3. Metode pengumpulan data

Pada tahap pengumpulan data, penulis menggunakan metode studi pustaka (John W. Creswell, 2013), yaitu dengan mencari dan membaca data yang berkaitan dengan pendidikan kebencanaan. Kemudian dilakukan pemilahan data untuk menentukan sumber data primer dan sumber data sekunder.

4. Teknik analisis data

Penulis menganalisis data menggunakan teknik analisis isi atau content analysis (Muhajir, 2000), yaitu dengan cara melakukan analisis secara mendalam terhadap literatur-literatur yang berkaitan dengan pendidikan kebencanaan.

\section{HASIL DAN PEMBAHASAN}

Pendidikan secara umum didefinisikan sebagai suatu proses yang membawa perubahan dalam perilaku masyarakat. Ini adalah proses yang memungkinkan individu secara efektif berkontribusi terhadap kemajuan masyarakat. Saat ini, peran pendidikan sebagai instrumen perubahan sosial diakui secara luas. Pendidikan telah membawa perubahan dalam sikap terhadap setiap aspek kehidupan. Melalui keluarga, sekolah, dan lembaga pendidikan tinggi, pendidikan sangat efektif dalam mempromosikan budaya keselamatan (Baytiyeh, 2018) yang mengacu pada seperangkat keyakinan yang dipelajari, keterampilan, kegiatan, dan kapasitas dalam meningkatkan perilaku pencegahan individu dan tindakan perlindungan untuk mengurangi risiko dan kerentanan terhadap bencana (Alexander, Bramati, \& Simonetta, 2009; Chou, Yang, \& Ren, 2015; Gaillard, Maceda, Stasiak, Le Berre, \& Espaldon, 2009; Hoffmann \& Muttarak, 2017).

Pendidikan tetap menjadi salah satu metode yang paling efektif untuk meningkatkan kesadaran risiko bencana di masyarakat rentan dan merupakan cara tercepat untuk menghasilkan hasil yang memuaskan dalam mitigasi risiko bencana. Pendidikan kebencanaan ini diterapkan kepada masyarakat sehingga masyarakat mengetahui peranannya dan mengetahui bagaimana menghadapai bencana (Addas, Kibsey, Ng, \& Walker, 2016; Brundiers, 2018; Johnson, Ronan, Johnston, \& Peace, 2014b; Muttarak \& Pothisiri, 2012; Paudel \& Ryu, 2018; Rambau, Beukes, \& Fraser, 2012; Sonneborn, Miller, Head, \& Cross, 2018). Dalam hal ini, pendidikan masyarakat adalah proses berkelanjutan di mana masyarakat memperoleh pengetahuan tentang peran, tanggung jawab, dan harapan untuk kesiapsiagaan individu serta cara di mana individu dapat bekerja dengan anggota masyarakat lainnya untuk menanggapi dan pulih dari bencana (Chandra et al., 2011). Pendidikan masyarakat merupakan pengetahuan penting untuk memastikan bahwa individu dan masyarakat terdidik tentang risiko bencana dan tahu bagaimana mempersiapkan diri, merespons, dan memulihkan diri. Pendidikan masyarakat juga berarti bahwa setiap orang tahu ke mana harus mencari bantuan baik untuk diri mereka sendiri dan tetangga mereka, yang memungkinkan seluruh masyarakat untuk tahan dalam menghadapi bencana (Frankenberg, Sikoki, Sumantri, Suriastini, \& Thomas, 2013; Jasper et al., 2013; Pascapurnama et al., 2018; Saroar, Routray, \& Filho, 2007; Shah \& Lopes Cardozo, 2014).

Perlunya ditekankan lagi bahwa pendidikan kebencanaan disini juga meliputi pendidikan kesiapsiagaan, pendidikan mitigasi bencana, pendidikan tanggap darurat bencana, pendidikan pemulihan akibat bencana, dan kegiatan pasca terjadi bencana. Berbagai macam cara dalam hal pendidikan telah dilakukan, yaitu dengan meningkatkan pengetahuan, keterampilan, sikap dan perilaku pencegahan bencana dan dengan menerapkan pengetahuan tersebut kedalam kehidupan sehari-hari. Nilai-nilai dan hasil belajar dapat meningkatkan kesiapsiagaan masyarakat dalam mengahadapi bencana yang terjadi di wilayahnya (Chou et al., 2015). Pelatihan adalah bagian dalam pendidikan yang berharga dari proses perencanaan sebelum terjadi bencana. Pemahaman yang lebih 
baik mengenai bencana sangat penting untuk dipelajari sebelum kejadian yang sebenarnya (Alexander et al., 2009).

Pendidikan kebencanaan sekarang diakui sebagai elemen penting dalam merumuskan strategi pengurangan risiko bencana yang tepat untuk negara manapun. Selama beberapa dekade terakhir, ada kemajuan luar biasa dalam mengembangkan dasar teoritis untuk manajemen bencana. Kemajuan dalam sains dan teknologi memungkinkan pemahaman yang lebih baik dan penyajian masalah risiko dan kerentanan (Melo Zurita et al., 2018; Muttarak \& Pothisiri, 2012; Nifa, Abbas, Lin, \& Othman, 2017; Pascapurnama et al., 2018). Para ilmuwan sosial telah berhasil mengeksplorasi berbagai dimensi sosial yang terkait dengan risiko dan kerentanan bencana (Shaw, Mallick, \& Takeuchi, 2015). Berbagai pengetahuan yang berkembang memungkinkan dalam pengembangan ilmu kebencanaan yang arahnya pada pendidikan kebencanaan. Tidak dapat dipungkiri bahwa pendidikan kebencanaan sangatlah penting, mengingat Indonesia sebagai "market bencana" yang memiliki kerawanan terhadap beberapa jenis bencana, baik bencana alam maupun bencana sosial. Kendatipun demikian, perlu suatu metode yang khusus dalam pendidikan kebencanaan dengan tujuan agar pendidikan yang diberikan kepada masyarakat dapat sesuai sasaran dan bermanfaat (Andrea \& Michele, 2016; Bajow et al., 2016; Faber et al., 2014; Johnson, Ronan, Johnston, \& Peace, 2014a; Prihatiningsih, Widyandana, Hapsari, Helmiyati, \& Ananda, 2017).

Tidak dapat dipungkiri bahwasanya pendidikan memiliki peran yang sangat penting dalam menentukan masyarakat untuk siap siaga dalam menghadapi bencana. Semakin intensif suatu pendidikan dan pengetahuan kebencanaan diberikan kepada masyarakat, maka semakin baik kapasitas masyarakat dalam menghadapai bencana (Kusumasari \& Alam, 2012; Melo Zurita et al., 2018; Nifa et al., 2017; Shiwaku \& Shaw, 2008; Wahyuni, Fitrah, \& Handayani, 2018). Menurut Hoffmann \& Muttarak (2017) bahwasanya efek dari pendidikan kebencanaan bahwasanya seseorang akan memiliki kemampuan kognitif, memiliki pengetahuan mengenai bencana, seseorang dapat memecahkan masalah dengan baik, dan meningkatkan persepsi serta tindakan yang harus dilakukan dalam penanggulangan bencana. Sampai saat ini belum ada metode yang tepat yang dapat digunakan dalam memberikan pendidikan kebencanaan, baik dalam lingkungan pendidikan formal, pendidikan non formal, ataupun pendidikan informal. Banyak penelitian memiliki keterbatasan metodologis meskipun ada bukti perubahan pengetahuan yang berharga, masih ada bukti empiris yang sangat terbatas tentang bagaimana program pendidikan bencana yang tepat (Johnson et al., 2014a).

Disisi lain, dalam memberikan pendidikan kebencanaan perlu adanya metode khusus dalam memberikan pemahaman kepada masyarakat (Tsai, Wen, Chang, \& Kang, 2015). Masyarakat memiliki tingkat pendidikan yang berbeda sehingga perlu memakai bahasa yang sederhana yang dapat digunakan dalam pendidikan kebencanaan (Andrea \& Michele, 2016). Dalam penelitian Andrea dan Michelle, metode yang tepat dalam pendidikan kebencanaan adalah metode flow chart yang mana di dalamnya memberikan pilihan sederhana kepada masyarakat dalam mengambil tindakan setelah terjadi bencana. Tindakan yang dilakukan setelah terjadi bencana akan memepengaruhi kejadian-kejadian diluar dugaan, masyarakat yang tidak pernah diberikan pendidikan bencana cenderung akan melakukan hal buruk yang dapat membahayakan keselamatannya (Rambau et al., 2012).

Keputusan sekecil apapun akan sangat bermanfaat dalam keselamatan. Hal inilah perlu diberikan metode khusus dalam pendidikan kebencanaan yang dapat dipahami masyarakat secara umum. Menurut Mulyasari, et al (2015) alat yang digunakan untuk menerapkan pendidikan kebencanaan kepada masyarakat harus disiapkan dengan baik sehingga masyarakat akan terbantu dengan konsep pendidikan yang ditawarkan oleh pelatih. Hal ini dilakukan dengan cara mengamati wilayah sekitarnya yang pernah atau berpotensi terhadap bencana, wawancara mendalam kepada tokoh masyarakat, kunjungan ke tempat tertentu yang bertujuan pendidikan, latihan penanggulangan bencana, menggali pengetahuan asli masyarakat, dan memberikan bahan-bahan tertulis (leaflet, poster, komik, dll.). Terdapat beberapa jenis metode pendidikan yang dapat diterapkan kepada masyarakat, antara lain: 
1. Pelatihan - pelatihan mencakup segala bentuk kegiatan seperti pelatihan berbasis ruang kelas, ceramah, latihan lapangan, di tempat kerja. Diantara berbagai metode pendidikan bencana, pelatihan adalah metode yang paling banyak digunakan untuk pendidikan non-formal (Fernandez, Uy, \& Shaw, 2012)

2. Kegiatan Peningkatan Kesadaran - Kegiatan peningkatan kesadaran adalah metode tertinggi kedua yang ditemukan di antara program yang diidentifikasi. Kategori ini mencakup semua program / proyek yang memiliki komponen peningkatan kesadaran dalam tujuan atau kegiatan mereka. Ini termasuk program / kegiatan / kampanye kesadaran publik, pemberdayaan masyarakat, kampanye pendidikan, kampanye informasi publik dan pertukaran informasi (Takako Chinoi, 2007)

3. Publikasi - Kategori publikasi termasuk publikasi apapun terkait dengan pendidikan bencana seperti buletin kebencanaan, publikasi ilmiah, pamflet, poster, buku, film, pedoman, dan materi pendidikan yang terkait dengan materi pelatihan bencana (Mulyasari et al., 2015)

4. Workshops dan Seminar - mengadakan kegiatan ini bertujuan untuk mengenalkan pendidikan kebencanaan kepada masyarakat dalam waktu yang singkat, biasanya mendatangkan ahli pendidikan kebencanaan yang sudah sering terlibat dalam workshop dan seminar (Takako Chinoi, 2007)

5. Demonstrasi, Latihan, Simulasi, dan Pameran - Kegiatan ini juga memiliki peran penting dalam pendidikan kebencanaan, kegiatan ini mengajarkan masyarakat dalam menghadapi bencana, cara mitigasi bencana, cara menangani tanggap darurat bencana, dan bagaimana pulih terhadap bencana (Takako Chinoi, 2007)

6. Kegiatan Pengembangan Kapasitas Lainnya - Pengembangan kapasitas lainnya termasuk program / proyek yang secara langsung atau tidak langsung menyediakan pendidikan non-formal. Ini termasuk kegiatan pengembangan keterampilan, pengembangan rencana manajemen bencana, komite penanggulangan bencana, pembentukan kelompok untuk manajemen bencana, studi banding, pendekatan pembelajaran partisipatif, transfer teknologi dan kegiatan pengembangan kapasitas lainnya yang berkaitan dalam pendidikan kebencanaan (Mulyasari et al., 2015).

Berdasarkan jenis metode pendidikan tersebut, perlu dikaji ulang bahwa pendidikan kebencanaan perlu mempertimbangkan kearifan local masyarakat yang sudah ada, artinya dalam memberikan pendidikan kebencanaan tidak boleh mengubah atau menghilangkan kearifan local yang ada dalam masyarakat. Kearifan local (indigenous knowledge) adalah suatu pengetahuan lokal masyarakat yang digunakan dalam menyikapi suatu permasalahan yang ada di masyarakat. Disamping itu, modal sosial adalah suatu indikator penting yang melekat dalam struktur hubungan sosial, dan memfasilitasi tindakan tertentu dari individu yang ada di dalam masyarakat (Hoque, Quinn, \& Sallu, 2017). Modal sosial menjadi tumpuan hidup di masyarakat, sehingga jika pendidikan bencana dikaitkan dengan kearifan local dan modal sosial akan menghasilkan hubungan yang sangat baik dalam pengurangan risiko bencana (Ganapati, 2008). Proses dalam pengembangan masyarakat memerlukan upaya untuk membangun sumber daya manusia yang berguna dalam meningkatkan kualitas dan kesejahteraan. Tugas utama seorang pengembang masyarakat dan seoarang pendidik adalah memberikan pengetahuan mengenai keilmuan yang dimiliki khususnya mengenai pendidikan kebencanaan yang dapat diimplementasikan dalam kehidupan sehari-hari (Green, 2016). Ada empat hal yang harus dimplementasikan dalam pengembangan masyarakat yaitu meningkatkan partisipasi masyarakat, memperluas jejaring komunitas, meningkatkan kemitraan, dan meningkatkan pengetahuan melalui pendidikan (Islam, 2017).

Menurut Twigg (2004) bahwa indigenous knowledge merujuk pada sistem pengetahuan yang dimiliki masyarakat, kearifan lokal masyarakat, persepsi dan sikap masyarakat dalam menangani bencana, dan keterampilan yang dimiliki masyarakat sebagai modal dalam menangani bencana. Kearifan local memiliki makna yang luas, misalnya masyarakat memiliki pengetahuan dalam membuat bangunan rumah, pengetahuan masyarakat mengenai dimana tempat yang akan 
digunakan untuk tempat tinggal, bagaimana masyarakat beradaptasi dengan lingkungan yang ditinggali, pengetahuan mengenai pekerjaan yang akan ditekuni, pengetahuan penggunaan sumber daya yang digunakan dalam mencukupi kebutuhan hidup, dan sikap masyarakat terhadap gejala alam atau fenomena yang ada di wilayahnya (lloka, 2016).

\section{KESIMPULAN}

Pendidikan bencana menjadi salah satu cara paling mudah dalam mentransfer pengetahuan kepada masyarakat yang bertujuan untuk memberikan wawasan kebencanaan sekaligus memberikan peringatan bahwa bencana dapat datang setiap saat, sehingga perlu waspada dan pengetahuan khusus dalam menghadapi bencana. Pendidikan bencana dapat berupa pelatihan, peningkatan kapasitas kebencanaan, simulasi bencana, publikasi karya yang berkaitan kebencanaan, dan lainnya yang berkaitan dengan peningkatan kapasitas terhadap bencana. Dalam memberikan pendidikan kebencanaan harus memperhatikan kearifan lokal masyarakat sehingga pemahaman masyarakat dalam mengahadapi bencana dapat sejalan dengan pengetahuan yang kita berikan.

\section{DAFTAR PUSTAKA}

Addas, A., Kibsey, S. D., Ng, G., \& Walker, T. (2016). Training the next generation of disaster risk managers through sustainability research and teaching. AD-Minister, (28), 157-176. https://doi.org/10.17230/ad-minister.28.8

Alexander, D., Bramati, L., \& Simonetta, M. (2009). Emergency Preparedness Training and Education in Lombardy Region, Italy: Survey of Supply and Demand. Natural Hazards Review, 10(3)(August), 77-83. https://doi.org/10.1061/(ASCE)1527-6988(2009)10:3(77)

Andrea, B., \& Michele, M. (2016). Influence Rather than Control: A New Approach for Disaster Education in The Immediate Aftermath of a Disaster. International Journal of Disaster Risk Reduction, 19, 112-117. https://doi.org/10.1016/j.ijdrr.2016.08.026

Bajow, N., Djalali, A., Ingrassia, P. L., Ragazzoni, L., Ageely, H., Bani, I., \& Corte, F. Della. (2016). Evaluation of a new community-based curriculum in disaster medicine for undergraduates. BMC Medical Education, 16(1), 1-8. https://doi.org/10.1186/s12909-016-0746-6

Barrow, R., \& Woods, R. (2006). An Introduction to Philosophy of Education (4th ed.). USA: Routledge.

Baytiyeh, H. (2018). Can Disaster Risk Education Reduce the Impacts of Recurring Disasters on Developing Societies? Education and Urban Society, 50(3), 230-245. https://doi.org/10.1177/0013124517713111

Black, N., Smeyer, P., Smith, R., \& Standish, P. (2003). Philosophy of Education. USA: Blackwell Publishing Ltd.

Brundiers, K. (2018). Educating for Post-Disaster Sustainability Efforts. International Journal of Disaster Risk Reduction, 27, 406-414. https://doi.org/10.1016/j.ijdrr.2017.11.002

Chandra, A., Acosta, J., Stern, S., Uscher-pines, L., Williams, M. V., Yeung, D., ... Meredith, L. S. (2011). Education: Ensure Ongoing Information to the Public About Preparedness, Risks, and Resources Before, During, and After a Disaster. JSTOR, (May 2018), 19-25.

Chou, J. S., Yang, K. H., \& Ren, T. C. (2015). Ex-Post Evaluation of Preparedness Education in Disaster Prevention, Mitigation and Response. International Journal of Disaster Risk Reduction, 12, 188201. https://doi.org/10.1016/j.ijdrr.2015.01.002

Deni Darmawan. (2013). Metode Penelitian Kuantitatif. Bandung: PT. Remaja Rosdakarya.

Faber, M. H., Giuliani, L., Revez, A., Jayasena, S., Sparf, J., \& Mendez, J. M. (2014). Interdisciplinary Approach to Disaster Resilience Education and Research. Procedia Economics and Finance, 18, 601-609. https://doi.org/10.1016/S2212-5671(14)00981-2

Fernandez, G., Uy, N., \& Shaw, R. (2012). Chapter 11 Community-Based Disaster Risk Management Experience of the Philippines. In Community, Environment and Disaster Risk Management (Vol. 10). https://doi.org/10.1108/S2040-7262(2012)0000010017 
Frankenberg, E., Sikoki, B., Sumantri, C., Suriastini, W., \& Thomas, D. (2013). Education, Vulnerability, and Resilience after a Natural Disaster. Ecology and Society : A Journal of Integrative Science for Resilience and Sustainability, 18(2), 16-28. https://doi.org/10.5751/ES-05377-180216

Gaillard, J. C., Maceda, E. A., Stasiak, E., Le Berre, I., \& Espaldon, M. V. O. (2009). Sustainable livelihoods and people's vulnerability in the face of coastal hazards. Journal of Coastal Conservation, 13(2), 119-129. https://doi.org/10.1007/s11852-009-0054-y

Ganapati, S. (2008). Critical Appraisal of Three Ideas for Community Development in the United States. Journal of Planning Education and Research, 27, 382-399. https://doi.org/10.1177/0739456X07313428

Green, J. J. (2016). Community Development and Social Development : Informing Concepts of Place and Intentional Social Change in a Globalizing World. Research on Social Work Practice, 26(6), 605-608. https://doi.org/10.1177/1049731515627194

Hamid, N. (2018). Study of Community Capacity in Dealing With The Threat of Shore Erosion in Kragan Subdistrict Rembang District. Pancaran Pendidikan, 7(3), 57-70. https://doi.org/10.25037/pancaran.v7i3.193

Henderson, S. (Van P. (1947). Introduction to Philosophy of Education. Chicago: University of Chicago Press.

Hoffmann, R., \& Muttarak, R. (2017). Learn From the Past, Prepare for the Future: Impacts of Education and Experience on Disaster Preparedness in the Philippines and Thailand. World Development, 96, 32-51. https://doi.org/10.1016/j.worlddev.2017.02.016

Hoque, S. F., Quinn, C., \& Sallu, S. (2017). Differential livelihood adaptation to social-ecological change in coastal Bangladesh. Regional Environmental Change, 18(2), 451-463. https://doi.org/10.1007/s10113-017-1213-6

Iloka, N. G. (2016). Indigenous knowledge for disaster risk reduction: An African perspective. Jàmbá: Journal of Disaster Risk Studies, 8(1), 1-7. https://doi.org/10.4102/jamba.v8i1.272

Islam, M. R. (2017). Non-governmental organizations and community development in Bangladesh. International Social Work, 60, 479-493. https://doi.org/10.1177/0020872815574133

Jasper, E., Berg, K., Reid, M., Gomella, P., Weber, D., Schaeffer, A., ... Berg, D. (2013). Disaster Preparedness: What Training Do Our Interns Receive During Medical School? American Journal of Medical Quality, 28(5), 407-413. https://doi.org/10.1177/1062860612471843

John W. Creswell. (2013). Research Design Pendekatan Kualitatif, Kuantitatif, dan Mixed (A. Fawaid, ed.). Yogyakarta: Pustaka Pelajar.

Johnson, V. A., Ronan, K. R., Johnston, D. M., \& Peace, R. (2014a). Evaluations of disaster education programs for children: A methodological review. International Journal of Disaster Risk Reduction, 9, 107-123. https://doi.org/10.1016/j.ijdrr.2014.04.001

Johnson, V. A., Ronan, K. R., Johnston, D. M., \& Peace, R. (2014b). Implementing disaster preparedness education in New Zealand primary schools. Disaster Prevention and Management, 23(4), 370-380. https://doi.org/10.1108/DPM-09-2013-0151

Kusumasari, B., \& Alam, Q. (2012). Local wisdom-based disaster recovery model in Indonesia. Disaster Prevention and Management: An International Journal, 21(3), 351-369. https://doi.org/10.1108/09653561211234525

Melo Zurita, M. de L., Cook, B., Thomsen, D. C., Munro, P. G., Smith, T. F., \& Gallina, J. (2018). Living with disasters: social capital for disaster governance. Disasters, 42(3), 571-589. https://doi.org/10.1111/disa.12257

Muhajir, N. (2000). Metode Penelitian Kualitatif. Yogyakarta: Rake Sarasin.

Mulyasari, F., Takeuchi, Y., \& Shaw, R. (2015). Chapter 7 Implementation Tools for Disaster Education. Disaster Education, 7, 137-151. https://doi.org/10.1108/MBE-09-2016-0047

Muri Yusuf. (2014). Metode Penelitian Kuantitatif, Kualitatif, \& Penelitian Gabungan. Jakarta: Prenadamedia Group.

Muttarak, R., \& Pothisiri, W. (2012). The Role of Education on Disaster Preparedness: Case Study of 2012 Indian Ocean Earthquakes on Thailand's Andaman Coast. 18(4), 1-30. 
https://doi.org/10.5751/ES-06101-180451

Nifa, F. A. A., Abbas, S. R., Lin, C. K., \& Othman, S. N. (2017). Developing a disaster education program for community safety and resilience: The preliminary phase. AIP Conference Proceedings, 1891, 1-7. https://doi.org/10.1063/1.5005338

Pascapurnama, D. N., Murakami, A., Chagan-Yasutan, H., Hattori, T., Sasaki, H., \& Egawa, S. (2018). Integrated health education in disaster risk reduction: Lesson learned from disease outbreak following natural disasters in Indonesia. International Journal of Disaster Risk Reduction, 29(July 2017), 94-102. https://doi.org/10.1016/j.ijdrr.2017.07.013

Paudel, J., \& Ryu, H. (2018). Natural disasters and human capital: The case of Nepal's earthquake. World Development, 111, 1-12. https://doi.org/10.1016/j.worlddev.2018.06.019

Prihatiningsih, T. S., Widyandana, Hapsari, E. D., Helmiyati, S., \& Ananda, A. J. N. (2017). A lesson learnt: Implementation of interprofessional education in disaster management at Faculty of Medicine Universitas Gadjah Mada, Indonesia. Journal of Interprofessional Education and Practice, 9, 121-125. https://doi.org/10.1016/j.xjep.2017.10.001

Rambau, T. S., Beukes, L. D., \& Fraser, W. (2012). Disaster Risk Reduction through school learners' awareness and preparedness. Jàmbá: Journal of Disaster Risk Studies, 4(1), 1-11. https://doi.org/10.4102/jamba.v4i1.61

Saroar, M., Routray, J. K., \& Filho, W. L. (2007). Livelihood Vulnerability and Displacement in Coastal Bangladesh: Understanding the Nexus. 9-31. https://doi.org/10.1017/CBO9780511542510

Shah, R., \& Lopes Cardozo, M. (2014). Education and social change in post-conflict and post-disaster Aceh, Indonesia. International Journal of Educational Development, 38, 2-12. https://doi.org/10.1016/j.ijedudev.2014.06.005

Shaw, R., Mallick, F., \& Takeuchi, Y. (2015). Chapter 5: Essentials of Higher Education in Disaster Risk Reduction: Prospects and Challenges. 7, 95-113. https://doi.org/http://dx.doi.org/10.1108/MRR-09-2015-0216

Shiwaku, K., \& Shaw, R. (2008). Proactive co-learning: A new paradigm in disaster education. Disaster Prevention and Management: An International Journal, 17(2), 183-198. https://doi.org/10.1108/09653560810872497

Sonneborn, O., Miller, C., Head, L., \& Cross, R. (2018). Disaster education and preparedness in the acute care setting: A cross sectional survey of operating theatre nurse's disaster knowledge and education. Nurse Education Today, 65(July 2017), 23-29. https://doi.org/10.1016/j.nedt.2018.02.015

Takako Chinoi. (2007). Disaster Education in Japan. In Disaster Education. Paris: Building Research Institute and National Graduate Institute for Policy Studies.

Tsai, M. H., Wen, M. C., Chang, Y. L., \& Kang, S. C. (2015). Game-based education for disaster prevention. Al and Society, 30(4), 463-475. https://doi.org/10.1007/s00146-014-0562-7

Wahyuni, H. I., Fitrah, A. A., \& Handayani, F. (2018). A comparative analysis of social adaptation to maritime disaster in Indonesia and Fiji. Pacifik Journalism Review, 24(1), 12-36.

Winch, C., \& Gingell, J. (2008). Philosophy of Education. The Key Concepts (2nd ed.). USA: Rouledge. 